\title{
Mark Tulij | PISMA BRATU KVINTU I, 1 \\ CICERON (O upravi province)
}

\author{
Prevod Alěs MAVER, \\ Marija Neža PIRC, Mitja SADEK, \\ Miran SAJOVIC in Nina VUK
}

(1) Čeprav ne dvomim, da bodo mnogi glasniki, pa tudi človeške govorice same $s$ svojo hitrostjo prehitele to pismo in boš tako že prej od drugih slišal, da se je mojemu hrepenenju in tvojemu naporu pridružilo še tretje leto ${ }^{2}$, vendar sodim, da ti moram tudi sam prenesti to nadležno novico. Kajti v prejšnjih pismih, in to ne v enem, marveč v mnogih, sem ti ohranjal upanje, da se boš mogel kmalu vrniti, čeprav so drugi nad tem že obupali. Tega nisem počel le, da bi te kar najdlje razveseljeval s to prijetno mislijo, marveč tudi zato, ker smo tako jaz kot pretorji vložili toliko napora, da nisem dvomil, da bi se naš namen ne mogel posrečiti. (2) Ker je zdaj tako naneslo, da niso mogli niti pretorji s svojim vplivom niti jaz s svojim prizadevanjem ničesar doseči, je seveda nadvse težavno prenesti zadevo ravnodušno. Pa vendar naju, ki sva se vajena spopadati in se kosati $z$ najzahtevnejšimi nalogami, taka nadloga ne sme zlomiti ali potreti. Kakor pa ljudje navadno najteže prenašajo tisto, kar se je zgodilo po njihovi krivdi, je pri tej reči nekaj, kar sam celo teže prenašam kakor ti. Po moji krivdi se je namreč zgodilo tisto, proti čemur si se pri meni zavzemal že, ko si odhajal, še bolj pa v svojih pismih, da preteklemu letu upravništva ne bi sledilo še eno. Nisem ravnal pametno, ko sem skrbel za dobrobit zaveznikov, ko sem se upiral nesramnosti ne maloštevilnih mešetarjev, ko sem skušal s tvojimi odlikami pomnožiti svojo slavo, zlasti še, ker sem dovolil, da je moglo to drugo leto tvoje službe pritegniti še tretje.

(3) Ker priznavam, da je to moja napaka, morata tvoja preudarnost in omikanost poskrbeti in narediti, da bo to, kar sem sam nespametno izpeljal, popravila tvoja marljivost. Če se boš še silneje spodbujal k temu, da bi se o tebi povsod govorilo le dobro, če boš tekmoval ne kakor $\mathrm{z}$ drugimi, marveč kakor s samim seboj, če bo slednjič vso tvojo razumnost, vso skrb in premislek usmerjala želja po odlični hvali v vseh rečeh, bo eno leto, dodano tvojemu naporu, lahko mi verjameš, dodalo mnoga leta radosti nama obema. Kajti slavo bo prinašalo še najinim potomcem.

\footnotetext{
${ }^{1}$ Prevod je nastal v okviru latinskega seminarja na Oddelku za klasično filologijo FF v zimskem semestru študijskega leta 2000/01.

${ }^{2}$ Kvint Tulij Ciceron je po preturi leta $61 \mathrm{pr}$. Kr. odšel za upravnika v provinco Azijo. Ker so mu upravništvo kar dvakrat podaljšali, je tam ostal vse do $58 \mathrm{pr}$. $\mathrm{Kr}$.
} 
(4) Zaradi tega te najprej prosim, da ti ne uplahne ali upade pogum in da ne dovoliš, da bi te obilica opravkov preplavila kakor hudournik, marveč se dvigneš zoper to in se upreš ali greš zadolžitvam celo naproti. Saj vendar ne upravljaš takega dela države, v katerem bi gospodarila usoda, marveč takega, v katerem največ štejeta razumnost in marljivost. Če bi videl, da bi ti bilo kot upravitelju podaljšano poveljstvo v kakšni siloviti vojni, bi v duši trepetal, saj bi vedel, da je bila sočasno podaljšana oblast usode nad nama. (5) Tako pa ti je bil zaupan tisti del države, v katerem nima usoda ali nobene vloge ali prav majhno in za katerega se zdi, da je ves v rokah tvoje krepostnosti in zmernega duha. Ni se nama treba bati, kakor menim, nobenih pasti sovražnikov, nikakega vojaškega spopada, nobene izdaje zaveznikov, ne pomanjkanja denarja ali prehrane, pa tudi ne upora v vojski. Vendar se celo zelo modrim možem pogosto zgodi, da ne zmorejo biti kos udarcem usode, kakor tudi najboljši krmarji niso kos divjanju nevihte. Tebi je bil naklonjen popoln mir, popolna spokojnost, vendar tako, da bi zmogla spečega krmarja celo preplaviti, budnega pa tudi razveseljevati.

(6) Znano je namreč, da sestavljajo prebivalstvo te province najprej zavezniki, ki so izmed vseh človeških rodov najbolj omikani ${ }^{3}$, ob njih pa taki naši državljani, ki so bodisi kar najtesneje povezani $\mathrm{z}$ nama, ker so davčni zakupniki ${ }^{4}$, bodisi sodijo, da sem jim jaz kot konzul obvaroval premoženje ${ }^{5}$, ker so premožni trgovci. (7) Vendarle med njimi samimi prihaja do resnih sporov, nastajajo številne krivice, iz njih pa izhajajo veliki prepiri. Saj govorim, kakor bi mislil, da nimaš nobenega dela! Vem, da je naloga nadvse zahtevna in terja tehten premislek, toda spomni se mojega mnenja, da je ta naloga prej stvar razuma kakor usode. Kaj je namreč takega brzdati tiste, ki jim načeluješ, če lahko brzdaš samega sebe? To naj bo, kakor tudi je zelo zahtevno, zahtevno in težavno za druge. Zate je bilo to zmeraj nekaj najlažjega in je tako tudi moralo biti za človeka s takšno naravo, da se zanjo zdi, da bi mogla biti zmerna celo brez izobrazbe, izobrazba pa, ki si je bil deležen, je tisto, kar bi moglo predrugačiti celo najbolj zakrknjeno naravo. Ko se boš sam upiral miku denarja, ko se boš upiral nasladi ali vsakovrstnemu poželenju, kakor počneš, bo, mislim, zares nastala nevarnost, da ne boš zmogel stopiti na prste nepoštenemu trgovcu ali nekoliko prepožrešnemu davčnemu zakupniku! Kajti Grki bodo, ko te bodo videli tako živeti, gotovo menili, da se je spustil v provinco nekdo iz bajeslovne preteklosti ali celo kak polbog iz nebes.

3 Misli seveda na Grke.

${ }^{4}$ Ker senatorjem ni bilo dovoljeno, da bi se ukvarjali z denarnimi posli, je velika večina davčnih zakupnikov pripadala stanu vitezov, iz katerega sta izhajala tudi Mark in Tulij Ciceron.

5 Med Katilinovo zaroto je bila ena od zahtev upornikov tudi odpis dolgov, ki bi za mnoge bogataše pomenil pravi finančni polom. 
(8) Tega ne pišem, da bi ti tako delal, marveč zato, da bi se veselil, ker tako že delaš in si delal. Skoraj neverjetno je namreč, da si prebil dve leti v Aziji kot vrhovni poveljnik tako, da te od popolne poštenosti in zmernosti ni odvrnil noben kip, nobena slika, nobena posoda, nobena tkanina, noben suženj, niti ne lepota kake ženske, pa celo ne denar, čeprav je vsega naštetega $v$ tej provinci v izobilju.

(9) Kaj je namreč moč najti tako izjemnega ali tako zaželenega kakor to, da taka plemenitost, zmernost duha, samoobvladovanje niso skrite nekje v temi, marveč so položene na azijsko sonce, pred oči najimenitnejše province in v ušesa vseh narodov in ljudstev? Da ljudi ni groza tvojih potov, da jih ne izmozgava tvoja potratnost, da jih tvoj prihod ne vrže iz tira? Da vlada, kamor koli prideš, bodisi javno bodisi zasebno, kar največje veselje, ker se zdi, da mesto sprejema varuha in ne trinoga, hiša pa gosta in ne plenilca?

(10) Izkušnje so te gotovo naučile, da v teh rečeh nikakor ni dovolj, da imaš sam te kreposti, temveč da se moraš temeljito ozreti okrog, da se bo videlo, da pri upravi province pred zavezniki, državljani in državo ne izstopaš le ti sam, marveč vsi tvoji podrejeni. Sicer pa imaš za legate take ljudi, ki bodo že sami po sebi skrbeli za tvoj ugled. Med njimi se po časti, ugledu in starosti odlikuje Tuberon ${ }^{6}$, o katerem sodim, da more, zlasti še, ker piše zgodovino, iz svojih analov izbrati mnoge, ki jih želi in more posnemati. Tudi najin Alien je po eni strani po naravi in dobrohotnosti, po drugi strani pa po svojem vedenju pravi zgled krepostnega življenja. Kaj naj nadalje rečem o Gratidiju? ${ }^{7}$ Zanj zagotovo vem, da se tako trudi za svoje dobro ime, da s tem zaradi bratske ljubezni do naju skrbi tudi za najino.

(11) Za kvestorja nimaš koga, ki bi ga izbral po lastni presoji, marveč tistega, ki ti ga je določil žreb. Že sam po sebi mora biti zmeren in se pokoravati tvojim pravilom in načelom. Če bi bil med njimi kdo preveč koristolovski, boš to prenašal, dokler bi sam zase kršil pravila, ki jim je zavezan, ne da bi izrabljal za svoj dobiček tisto oblast, ki si mu jo dodelil kot znamenje dostojanstva. Zares mi pa ne ugaja, da preiskuješ vsako malenkost in da kaznuješ vsakogar izmed njih, zlasti še, ker podrejeni svoj značaj kmalu navadijo na preveliko udobje in prizadevanje za naklonjenost, marveč, da vsakomur poveriš toliko opravkov, kolikor mu zaupaš. Za tiste, ki ti jih za spremljevalce in pomočnike $v$ javnih zadevah dala država, boš jamčil le $v$ okvirih, ki sem jih že prej navedel.

(12) Kar pa zadeva tiste, o katerih si hotel, da bi bili s teboj bodisi kot domače osebje bodisi kot osebni služabniki, ki jih navadno imenujejo nekake telesne stražarje, morajo biti ne le njihova dejanja, temveč tudi njiho-

\footnotetext{
"Lukij Ajlij Tuberon, eden mlajših analistov.

7 Mark Gratidij, Ciceronov daljni sorodnik.
} 
ve besede povsem skladne $z$ najinimi navodili. Vendar imaš s seboj take ljudi, ki jih moreš zlahka ceniti, če ravnajo prav, če pa premalo skrbijo za tvoj ugled, jih moreš zlahka obrzdati. Zdi se, da so, dokler si bil še neizkušen, ti znali pretentati tvojo velikodušnost (kajti, če je mož sam brezgrajen, zelo težko sumi, da so drugi nepošteni). Naj se torej to tretje leto odlikuje po isti poštenosti kakor prejšnji dve, ta pa naj bo preudarnejša in skrbnejša. (13) Troja ušesa naj bodo taka, da bodo sodila, da slišijo le tisto, kar (dejansko) slišijo, ne pa taka, da bi vanje šepetali izmišljotine in hlinjeno prijaznost zaradi dobička. Tvoj prstan naj ne bo kot kakšna posoda, marveč kakor ti sam, ne služabnik tuje volje, marveč priča tvoje. Uradni sluga naj ima tak položaj, kakršnega so zanj hoteli naši predniki, ki te službe ne kot znamenje ugodnosti, temveč kot zadolžitev in obveznost - niso naključno zaupali nikomur razen osvobojencem, ki jim niso ukazovali skoraj nič manj strogo kakor sužnjem. Liktor naj ne bo služabnik lastne, marveč tvoje blagosti, butare in sekire pa naj nosijo bolj kot znamenja dostojanstva kakor oblasti. Po vsej provinci naj bo znano, da so ti najpomembnejši blagor, otroci, ugled in premoženje vseh, ki jim stojiš na čelu. Prav tako naj se uveljavi mnenje, da boš, če boš za to le izvedel, sovražen ne samo tistim, ki sprejemajo podkupnine, temveč tudi tistim, ki jih dajejo. Ničesar več pa ne bodo dajali, če se bo razvedelo, da tisti, ki zatrjujejo, da imajo pri tebi veliko veljavo, $v$ resnici od tebe ne dosežejo ničesar.

(14) Tega nikakor ne govorim tako, kakor bi želel, da bi bil ti do svojih pretrd ali sumničav. Če je namreč (med njimi) kdo, za katerega nisi v dveh letih nikoli imel razloga, da bi ga sumil grabežljivosti, kar sam slišim in sodim, da sem to s teboj vred ugotovil o Kajsiju, Hajripu in Labeonu, ni nič takega, o čemer bi menil, da tem in še komu drugemu takih odlik tega ne smeš zaupati ali poveriti. Če pa je kdo tak, da si z njim že imel težave, da o njem kaj sumiš, temu ne verjemi ničesar in mu ne prepusti v varstvo nobenega kosa svojega dobrega imena.

(15) C̆e si v sami provinci našel koga, ki je vstopil globoko v tvojo zasebnost, pa nama je bil poprej neznan, le glej, koliko mu smeš zaupati! Saj ne, da ne bi mogli biti številni ljudje iz province poštenjaki. Toda to smemo upati, presojati o tem je nevarno. Posameznikova narava je namreč zakrita z mnogimi tančicami svetohlinstva in zagrnjena kakor z nekakšnim pajčolanom. Čelo, oči, obraz lažejo zelo pogosto, najpogosteje pa govor. Kako lahko zatorej kaj najdeš med ljudmi te vrste? Saj se vendar odpovedujejo vsem tistim rečem, od katerih naju ne more nič odtrgati, ker jih je zmamil pohlep po denarju, tebe pa, tujega človeka, naj bi ljubili iz vsega srca in se ne zgolj hlinili zaradi koristi? Vsaj meni se to zdi zelo težavno, posebno še, če isti ljudje nimajo radi skoraj nobenega zasebnika, upravnike pa vse po vrsti. Če si vendarle srečal med njimi koga, ki ima raje tebe samega kakor tvoj položaj (to bi se namreč moglo primeriti), takega brez 
zadržkov prištej med svoje. Če pa tega ne boš opazil, se moraš zaupnosti s tako vrsto ljudi varovati bolj kot $s$ katero koli drugo, ker poznajo vse poti denarja in tudi vse počno zaradi denarja ter jim ni prav nič mar za dobro ime tistega, $\mathrm{s}$ katerim jim ne bo treba živeti.

(16) Tudi se je treba varovati izrazov prijateljstva Grkov samih, z izjemo zelo redkih, če je kdo vreden stare Grčije. Zdaj so namreč mnogi med njimi neiskreni in se obračajo po vetru, dolgotrajno suženjstvo pa jim je privzgojilo čezmerno klečeplaznost. Pravim, da jih je sicer vse potrebno velikodušno sprejeti, $\mathrm{z}$ najboljšimi med njimi se tudi povezati z gostinskim prijateljstvom; pretesne zveze z njimi pa niso niti častne niti zanesljive. Ne upajo si namreč nasprotovati našemu mnenju in ne sovražijo le nas, marveč celo svoje ljudi.

(17) Ker bi želel biti previden in skrben že pri tovrstnih zadevah, za katere se celo bojim, da ne bi bil (v njih) pretrd, kaj meniš, kako gledam na sužnje? Te moramo tako ali tako povsod držati na kratko, zlasti pa še v provinci. O tej stvari bi se dalo dati mnogo naukov, toda najkrajši in tak, da si ga je najlaže zapomniti, je ta, naj se na azijskih potih obnašajo tako, kakor bi hodili po Apijevi cesti. Tudi naj nihče ne misli, da je kaka razlika, če gre v Trale ali v Formije. Če je kdo med sužnji izjemno zanesljiv, naj ti služi doma in v zasebnih zadevah: izmed tistih reči pa, ki zadevajo izvajanje tvoje službe ali kako državno zadevo, naj se ne pritakne ničesar. Številnih opravkov, ki bi jih bilo moč po pravici zaupati zanesljivim sužnjem, jim vendarle ne gre zaupati, da bi se izognil obrekovanju in graji.

(18) Toda ne vem, kako, da se je moje pismo sprevrglo v dajanje nasvetov, čeprav to spočetka ni bil moj namen. Kako naj namreč dajem nasvete komu, za katerega vem, da posebej v tej zadevi ne zaostaja za menoj po preudarnosti, po izkušnjah pa me celo prekaša? Kljub temu menim, da ti bo tisto, kar počneš, prijetnejše, če se temu pridruži moja potrditev. Zaradi tega naj bodo temelji tvojega ugleda naslednji: najprej tvoja poštenost in zmernost, nato spodobnost vseh, ki so s teboj, previdno in skrbno izbiranje bližnjih sodelavcev med Italiki v provinci in Grki, med sužnji pa trden in stalen red. (19) Ker je vse to častno že v najinih zasebnih in vsakdanjih opravilih, je nujno, da je pri tolikšnem obsegu pristojnosti, pri tako spačenih nraveh in $\mathrm{v}$ tako pokvarjeni provinci videti kot od bogov dano. To načelo in ta red lahko pri ukrepanju in odločanju ohranita ono odločnost, ki si jo kazal v zadevah, zaradi katerih sva si nakopala precej zamer, sicer na moje veliko veselje, razen če morda meniš, da so me užalostile pritožbe nekakega Pakonija, ki še Grk ni, temveč prej Mizijec ali Frigijec, ali gobezdanje Tuskena, jeznoritega in pokvarjenega človeka, ki si mu iz umazanega goltanca povsem upravičeno izdrl predmet umazanega pohlepa. (20) To in drugo, kar si z vso strogostjo ukrenil v provinci, bi le stežka vzdržala brez največje nravne moči. Zato naj pri deljenju pravice vlada strogost, da 
je le ne prilagajaš zaradi osebne naklonjenosti, marveč ostaja za vse enaka. $\mathrm{Pa}$ vendar malo zaleže, da ti sam pravično in skrbno razsojaš, če ne bodo prav tako ravnali tisti, ki jim boš prepustil kak kos te naloge. Zdi se mi, da pri upravi Azije raznolikost opravil sploh ni velika, da pa vsa provinca v največji meri sloni na sodstvu. Kar se tega tiče, je osnovno načelo, zlasti, ko gre za province, preprosto: potrebni sta stanovitnost in resnost, ki nista neobčutljivi le za osebno naklonjenost, marveč tudi za sumničenja.

(21) Pridružiti jima je treba še pozornost pri poslušanju, popustljivost pri odločanju, pri pomirjanju in v sporih pa natančnost. Zaradi teh zmožnosti je bil nedavno tega zelo priljubljen Gaj Oktavij*, pri katerem je bil tiho prvi liktor, molčal je služabnik; vsakdo je govoril, kadar koli je hotel in kakor dolgo je hotel. Zaradi tega bi se morda zdel preblag, ko ne bi ta blagost varovala njegove strogosti. Prisilil je namreč Sulove ljudi, da so vrnili, kar so si s silo in ustrahovanjem prisvojili. Kar so kot uradniki krivično določili, temu so se morali kot zasebniki pokoravati. Ta njegova strogost bi se zdela neznosna, ko je ne bi blažil s številnimi začimbami človečnosti.

(22) Če je taka prijaznost priljubljena v Rimu, kjer vladajo tolikšna objestnost, tako nebrzdana svoboda, tako neskončna samopašnost ljudi, kjer je nadalje toliko uradnikov, toliko pomočnikov v stiski, kjer ima ljudstvo toliko moč in senat tolikšen vpliv, kako prijetna more biti upravnikova ljudomilost šele v Aziji! Tam tolika množica državljanov in zaveznikov, toliko velikih mest, toliko občin upira svoj pogled v migljaj enega. Tam ni pomočnikov ne možnosti pritožbe_ne senata, pa tudi ne skupščine. Zato je dolžnost velikega človeka, ki je po eni strani že po naravi zmeren, po drugi strani pa tudi izveden v učenosti in v vseh najboljših veščinah, da ob toliki moči ravna tako, da si tisti, ki jim načeluje, ne bi želeli nobene druge oblasti, (23) kakor je Ksenofont upodobil slavnega Kira, ne po zgodovinski resnici, marveč da bi podal zgled pravičnega vladanja. Omenjeni filozof je združil njegovo največjo strogost $z$ nenavadno ljudomilostjo. Te knjige naš Afričan - ne brez razloga - skoraj nikoli ni dal iz rok. V njej namreč ni izpuščena nobena dolžnost skrbnega in zmernega vladarja. Ce je te dolžnosti tako izpolnjeval tisti, ki mu ni bilo treba nikoli biti zasebnik, kako se jih morajo držati šele oni, ki jim je bila oblast prav tako izročena, kakor jo pozneje vrnejo, in sojim jo dali prav tisti zakoni, h katerim se morajo povrniti.

(24) Zdi se mi pa, da morajo tisti, ki načelujejo drugim, vse obrniti na to, da bi bili tisti, ki so pod njihovo oblastjo, kar najbolj zadovoljni. Brž ko si stopil v Azijo, so stalen dober glas in govorice vseh razglašali, da je tebi to

* GAJ OKTAVIJ, oče poznejšega cesarja Oktavijana, ki je bil l. 61 pr. Kr. pretor, nato pa propretor v Makedoniji. 
najpomembnejše in ti je že od vsega začetka bilo. Dolžnost ne samo tistega, ki ima pod seboj zaveznike in državljane, marveč tudi onega, ki je postavljen nad sužnje in nad nemo živino, je namreč, da služi blagru in dobrobiti tistih, ki jih ima v oblasti.

(25) Ugotavljam, da je vsem znano, da si v to vložil kar največ truda. Da mestnim skupnostim nisi nakopal nobenega novega dolga, mnoge pa rešil starih bremen; da si na novo postavil številna porušena in domala zapuščena mesta, med njimi preslavni mesti Jonije in Karije, Samos in Halikarnas; da v mestih ni nobenih uporov, nobenih prepirov; da si poskrbel, da upravljajo mestne skupnosti sveti optimatov; da si iz Mizije pregnal razbojništvo, na mnogih krajih pa odvrnil poboje, po vsej provinci vzpostavil mir; da si zatrl roparske združbe, ne le tiste ob poteh in poljih, marveč tudi številčnejše in bolj razvejane po mestih in ob svetiščih; da si od dobrega glasu, premoženja in prostega časa premožnih odvrnil tisto najnevarnejšo služabnico upravnikovega pohlepa, spletko; da stroške in dajatve mestnih skupnosti enakomerno nosijo vsi, ki žive na ozemlju teh mest; da je dostop do tebe zelo preprost, da so tvoja ušesa odprta pritožbam vseh, da nista pred nikogaršnjo stisko zaprta ne samo ljudsko sodišče in sodni dvor, marveč celo ne tvoja hiša in spalnica, in da skratka na vsem območju tvoje oblasti ni nič neprijaznega, nič krutega, vse pa da je polno miline, blagosti in človečnosti.

(26) Kako neizmerna pa je šele tista tvoja zasluga, da si ob velikih težavah zame Azijo rešil krivičnega in gromozanskega edilskega ${ }^{8}$ davka! Če se namreč neki imenitnik vpričo tebe priduša, da si mu iztrgal dvesto tisoč sestercev", ker si odločil, naj se denar ne potroši za igre, koliko denarja bi se nabralo, če bi ga zahtevali za vse, ki v Rimu prirejajo igre (kakor je bila že navada)? Sicer pa sva vse te obtožbe zatrla s tistim sklepom (za katerega ne vem, koliko ga hvalijo v Aziji, v Rimu ga z nemajhnim občudovanjem), da sem, čeprav so mestne skupnosti namenile denar za gradnjo najinega spomenika in svetišča, in čeprav so to storile prostovoljno spričo mojih velikih zaslug in zaradi tvojih velikih uslug ter je zakon izrecno predvideval, naj se sredstva potrošijo za svetišče in spomenik, vendarle presodil, da tega, kar bi bilo dostojno in v skladu z voljo tistih, ki so se tega lotili, ne gre sprejeti, čeravno to, kar bi bilo narejeno, nikakor ne bi šlo v nič, marveč bi bilo v okras svetišču, tako da se mi zdi, da ne bi bilo bolj posvečeno meni kakor rimskemu ljudstvu in nesmrtnim bogovom. Ob drugih razlogih me je $\mathrm{k}$ tej odločitvi vodilo tudi to, da bi tisti, ki jim taka počastitev ne pripada niti jim ni namenjena, to laže prenesli.

${ }^{8}$ Edili so bili med drugim zadolženi tudi za organizacijo iger, saj Ciceron (De legibus 3,7) pravi, da so "curatores urbis, annonae, ludorum sollemnium «

Več kot pol milijarde slovenskih tolarjev. 
(27) Zaradi tega se $\mathrm{z}$ vsem srcem in $\mathrm{z}$ največjo vnemo usmeri v tisti cilj, ki si se mu že doslej posvečal, da namreč skrbiš za tiste, ki sta jih senat in rimsko ljudsko izročila in zaupala tvoji zanesljivosti in moči, jih v vsakem oziru varuješ in hočeš, da bi bili kar najsrečnejši. Če bi te žreb postavil na čelo Afričanom, Hispancem ali Galcem, divjim in neomikanim plemenom, bi bilo zate kot omikanega človeka vendarle primerno, da bi služil njihovi dobrobiti, koristi in blaginji. Ker pa sva postavljena na čelo tistemu rodu, ki mu je omika ne le domača, marveč se celo misli, da je od njega prešla na druge, morava to omiko zagotovo izročiti v najboljši obliki tistim, od katerih sva jo prejela. (28) Ne bo me namreč sram povedati, še zlasti ne pri takem življenju in pri teh dosežkih, ob katerih ne more biti niti najmanjšega suma nesposobnosti ali lahkomiselnosti, da sem tisto, kar sem dosegel, dosegel s pomočjo znanja in veščin, ki so mi jih posredovale grške vede in stroke. Zato se zdi, da smo poleg splošne odprtosti, ki smo jo dolžni vsem ljudem, še posebej zavezani temu ljudstvu in da si prizadevamo pri tistih, po katerih naukih smo se vzgajali, pokazati, kaj.smo se naučili.

(29) Tudi Platon, prvi med misleci in učenjaki, je menil, da bodo države šele tedaj srečne, ko jim bodo bodisi začeli vladati učeni in modri možje bodisi bodo tisti, ki vladajo, vse svoje prizadevanje posvetili učenju in filozofiji. Sodil je, da more biti taka povezava med oblastjo in modrostjo državam v prid. To se je morda nekoč že uresničilo v vsej naši državi ${ }^{10}$, zdaj pa se zagotovo uresničuje $\mathrm{v}$ tej provinci, da ima namreč v njej vrhovno oblast tisti, ki je od otroštva največ truda in časa posvetil temu, da bi si pridobil krepost in omiko.

(30) Spričo povedanega poskrbi, da se bo zdelo, da je bilo to leto, ki je bilo dodano tvojemu napornemu delu, dodano v blagor Azije. Ker je bila v prizadevanjih, da bi te obdržala, Azija srečnejša kakor jaz v svojih, da bi te pripeljal nazaj, stori, da bo zadovoljstvo province ublažilo moje hrepenenje. Če si bil namreč nadvse skrben v tem, da si si pridobil časti, ki so ti jih izkazovali toliko kot menda še nikomur, moraš še veliko večjo skrb nameniti temu, da si te časti ohraniš. (31) Kaj si mislim o tovrstnih časteh, sem ti pisal že prej. Zmeraj sem bil mnenja, da so, če so vsakdanje, neznatne, če jih izkazujejo zaradi položaja, brez teže; če pa so bile podeljene, kakor se je zgodilo tukaj, tvojim zaslugam, sodim, da moraš precejšen trud posvetiti varovanju le-teh. Zatorej boš, ker imaš najvišjo moč in oblast v tistih mestih, za katera veš, da so povzdignila tvoje kreposti in jih uvrstila med bogove, pri vseh zadevah, ki jih boš presojal, o njih odločal in jih izvrševal, temeljito razmislil, kaj dolguješ takšnemu javnemu mnenju, takšnim sodbam o sebi in takim počastitvam. To boš dosegel na tak način, da boš skrbel za vse, da boš pomagal ljudem v stiski, da boš imel vedno pred očmi njihovo blagi-

${ }^{10}$ Ciceron najbrž meri na čas svojega konzulata. 
njo in da si boš prizadeval (boš hotel), da bi te vsa Azija imenovala in te dejansko imela za očeta.

(32) Veliko težav ti v tem hotenju in prizadevanju delajo davčni zakupniki. Če jim nasprotujeva, bova ta za naju tako zaslužen in po naju z državo povezan stan odtrgala tako od naju kot od države; če pa jim bova v vsem popuščala, bova dopustila izkoriščanje tistih, ki sva jim dolžna zagotoviti ne le blagor, marveč tudi znosno življenje. To je, če hočemo prav premisliti, edina težava na vseh področjih tvoje oblasti. Kajti to, da si zmeren, da se vzdržiš vsakega pohlepa, da brzdaš svoje uradnike, da vzdržuješ pravične sodne postopke, da si skrben pri poizvedovanju o stvareh, da si prijazen pri poslušanju in sprejemanju ljudi, prinaša več slave, kakor pa je $v$ resnici težavno. Ni namreč stvar nekega napora, temveč nekake duševne usmeritve duha in volje. (33) Koliko ogorčenja zbuja pri zaveznikih zadeva z davčnimi zakupniki, smo videli ob državljanih, ki se nedavno ob italskih carinskih postajah niso toliko pritoževali nad samo carino kot nad krivičnim ravnanjem nekaterih carinikov. Zato še predobro vem, kaj se dogaja zaveznikom v oddaljenih deželah, ko vendar že v Italiji slišim pritožbe državljanov. Zato se mi zdi tvoje ravnanje, da zadovoljiš zakupnike, posebno še, ker je bilo javno ozemlje odkupljeno pod ceno, in pri tem ne dovoliš propada zaveznikov, stvar nekake božanske kreposti, to je tvoje.

Najprej se to, kar zbuja pri Grkih največ nejevolje, da so namreč davčni zavezanci, le-tem ne sme zdeti tako grozno, ker so bili v enakem položaju tudi brez uradnikov rimskega ljudstva, pod domačo oblastjo. Ustanove davčnih zakupnikov pa tudi ne morejo zavračati, ko vendar brez zakupnika niso zmogli plačati davka, ki jim ga je sorazmerno predpisal Sula ${ }^{11}$. Da pa pri izterjevanju davkov Grki niso nič bolj prizanesljivi od naših zakupnikov, se vidi po tem, da so se Kavnijci ${ }^{12}$ in prebivalci vseh tistih otokov, ki jih je Sula dodelil Rodijcem, nedavno zatekli pred senat, da bi davek raje plačevali nam kakor pa Rodijcem. Spričo tega se ustanove zakupnikov ni treba bati tistim, ki so že vedno bili davčni zavezanci, ne smejo jih zavračati tisti, ki sami niso zmogli plačevati davka, nasprotovati pa jim ne tisti, ki so jih sami zahtevali. (34) Hkrati naj Azija pomisli na to, da ji ne bi bila prihranjena nobena nevarnost, ne vojne $z$ zunanjim sovražnikom ne notranjih razprtij, če ne bi bila pod to oblastjo. Ker pa te oblasti ni mogoče na noben način ohraniti brez davkov, naj si z delom svojih sadov ravnodušno kupuje večni mir in brezskrbnost. (35) Če pa bodo mogli ravnodušno prenašati sam stan in ustanovo davčnih zakupnikov, se jim lahko zaradi tvoje

\footnotetext{
"Med prvo vojno z Mitridatom je Sula za potrebe vojske od prebivalcev Azije zahteval, naj v enem letu zberejo davek, ki bi ustrezal vsoti petih običajnih davčnih let. Ker tolikšne vsote niso mogli zbrati, so vsoto plačali davčni zakupniki in jo potem izterjali - kajpak z obrestmi.

12 Prebivalci mesta Kavnos v jugovzhodni Kariji.
} 
razumnosti in preudarnosti zdijo manj boleče tudi ostale zadeve. Tako se pri sklepanju pogodb ni treba strogo ozirati na cenzorski zakon ${ }^{13}$, marveč bolj na koristnost sklepanja poslov in na reševanje pred odvečnimi težavami. Moreš delati tudi to, kar si že izvrstno počel in počneš, da namreč opozarjaš, kolikšen ugled imajo davčni zakupniki in koliko sva dolžna temu stanu, da s svojo naklonjenostjo in ugledom povezuješ zakupnike z Grki, ne da bi pri tem vpletal svojo oblast in dostojanstvo, obenem pa od tistih, za katere si tako zaslužen in ki ti dolgujejo vse, zahtevaš, da nama s svojo uvidevnostjo omogočijo obdržati in ohranjati tisto bližino, ki je med nama in zakupniki.

(36) Toda čemu te spodbujam $\mathbf{k}$ temu, kar bi ti ne le mogel izvrševati po svoji volji brez kakršnih koli naukov, marveč si to v veliki meri že dosegel? Ne nehajo se mi namreč vsak dan zahvaljevati najodličnejše in največje združbe zakupnikov, kar mi je še toliko prijetneje, ker isto delajo Grki. Težavno je namreč zgolj z osebnim prizadevanjem povezati tisto, kar se razlikuje glede na ugodnosti in koristi in že skoraj po naravi. Tistega, kar sem zapisal zgoraj, seveda nisem zapisal, da bi te poučeval (saj kot preudaren človek ne potrebuješ nikakršnih naukov), vendar me je pri pisanju razveseljevalo omenjanje tvoje vrline. Sicer pa sem v tem pismu daljši, kakor sem bodisi hotel biti bodisi sem mislil, da bom.

(37) Je pa nekaj, česar ti ne bom nehal naročati in ne bom trpel, kolikor je v moji moči, da bi te hvalili zgolj z zadržkom. Vsi, ki prihajajo od tam, govorijo namreč o tvoji kreposti, poštenosti in omikanosti na tak način, da izvzemajo, ko te sicer na vso moč hvalijo, edinole vzkipljivost. Ker se ta napaka že v zasebnem in vsakdanjem življenju kaže kot znamenje šibkega in nestanovitnega duha, ni nič tako grdega kakor to, da kdo s svojo vrhovno oblastjo združi kruto naravo. Zato se ne bom polotil tega, da bi ti na tem mestu razlagal, kaj so o vzkipljivosti govorili največji učenjaki, ker po eni strani nočem biti predolg, po drugi strani pa se o tem lahko zlahka poučiš iz spisov mnogih piscev. Kljub temu menim, da ne smem izpustiti tistega, kar sodi k pismu, to je, da človeka, ki mu pišeš, seznaniš s tistim, česar ne ve.

(38) Skoraj vsi mi poročajo tole: kadar nisi podvržen besu, navadno rečejo, ne more biti nič prijetnejše od tebe. Toda brž ko te razkači kaka nepoštenost in izprijenost, se v duši tako razburiš, da nenadoma vsi pogrešajo tvojo človečnost. Zaradi tega se, ker sta naju ne toliko kakšna častihlepnost kot sam položaj in usoda pripeljala do tega, da bodo ljudje vedno govorili o naju, varujva, kolikor moreva pač storiti in doseči, da ne bodo govorili, da naju je kazila očitna pomanjkljivost. Ne zavzemam se za to, da

${ }^{18} \mathrm{~V}$ cenzorskem zakonu (lex censoria) so bili navedeni pogoji, pod katerimi so davčni zakupniki najemali državne dajatve za 5 let. 
bi spremenil svoj značaj, kar je morda že po naravi, še zlasti pa v najini starosti težavno, in da bi, če je kaj globoko vraščeno v nravi, to nemudoma izkoreninil. Če se ji že ne moreš povsem izogniti, te vendarle opominjam, da se, ker tvojega duha napolni bes, še preden more razum kaj vplivati, vsak dan vnaprej pripraviš in misliš na to, da se je potrebno vzkipljivosti upirati. In kadar ta najbolj razburka duha, tedaj moraš kar najskrbneje brzdati jezik, kar se mi včasih ne zdi nič manjša vrlina od te, da bi se sploh ne jezil. Kajti slednje ni le znamenje resnosti, temveč pogosto tudi brezbrižnosti. Obvladovati se pa v misli in besedi, kadar si jezen, ali celo molčati in obdržati vznemirjenost in strast pod nadzorom, je, čeprav ne znak popolne modrosti, vendarle znak nadpovprečne sposobnosti.

(39) Poročajo sicer, da si, kar se tega tiče, že mnogo bolj umirjen in blag. Ne prihajajo več do mene novice o kakih tvojih večjih živčnih izpadih, o nikakršnih psovkah ali žalitvah. Po eni strani se vse to ne sklada z izobrazbo in civiliziranostjo, po drugi strani pa je v nasprotju s (tvojo) oblastjo in dostojanstvom. Kajti če je jeza nepomirljiva, je to razumljeno kot najhujša krutost; če pa je popustljiva, je to resda znamenje nedoslednosti, ki pa ji je v težavah vendarle treba dati prednost pred okrutnostjo. (40) A ker se je prvo leto zelo veliko govorilo o tej tvoji slabosti - menim, da zaradi tega, ker so se nadte v nepričakovanem obsegu zgrnili krivičnost, pohlep in nesramnost ljudi in so se ti zdeli neznosni - drugo leto pa je bilo že mnogo bolje, ker so te izkušnje in razum in, kot sodim, tudi moja pisma, naredili bolj potrpežljivega in blagega, mora biti tretje leto tako brezhibno, da ne bo niti najmanjše reči, ki bi jo mogel kdo grajati.

(41) Na tem mestu te ne pozivam ali ti naročam, marveč te $v$ bratovskih prošnjah rotim, da ves svoj napor, skrb in razmislek usmeriš k temu, da bi si vsepovsod pridobil vsesplošno hvalo. Če bi bil najin položaj le domena vsakdanjih pogovorov in govoric, bi se od tebe ne zahtevalo nič izjemnega, nič neobičajnega. Tako pa se zaradi sijaja in veličine nalog, ki sva jih deležna, zdi, da se bova, če v tej provinci ne doseževa kar največje hvale, le stežka mogla izogniti zelo hudi graji. Ta najin položaj je pač tak, da vsi dobri, ker so nama naklonjeni, tudi terjajo in pričakujejo od naju prizadevnost in sposobnost, za vse nepoštene, ki sva jim napovedala večno vojno, pa se zdi, da so zadovoljni že $z$ najmanjšim povodom za grajo. (42) Ker je torej tvojim sposobnostim dano na voljo gledališče vse Azije, natrpano $z$ obiskovalci, zelo razsežno, izurjeno v presojanju, po naravi pa tako odmevno, da prinaša namige in žvižge vse do Rima, si, prosim, prizadevaj in se potrudi, da se bo zdelo ne le, da si bil vreden teh reči, marveč da si s svojo veščino tudi vse presegel. (43) In ker je naključje meni z uradnimi službami namenilo upravo mesta, tebi pa upravo province, poskrbi, da bo, če se moj delež ne umakne pred nikomer, tudi tvoj posekal ostale. Hkrati pomisli na to, da se ne trudiva več za še preostalo in šele pričakovano slavo, 
marveč se boriva za že pridobljeno, za katero si nama ni bilo potrebno tako prizadevati, kakor jo morava zdaj varovati. Če bi moglo biti v mojem življenju kar koli ločeno od tebe, si ne bi ničesar bolj želel kakor to, da bi bil to položaj, ki sem ga že dosegel. Zdaj je pa s stvarjo tako, da menim, da nisem ob tolikih svojih naporih in $v$ tolikih nevarnostih, ki si jih bil tudi ti deležen, dosegel ničesar, ko ne bi bila vsa tvoja dejanja in besede od tam v skladu z mojim položajem. Če si bolj kot drugi pripomogel, da sva si pridobila velikanski sloves, si boš gotovo enako bolj kot drugi prizadeval, da ga ohraniva. Ne smeš se namreč ozirati zgolj na mnenja in sodbe ljudi, ki žive zdaj, temveč tudi (na mnenje) tistih, ki bodo šele prišli; njihova sodba bo vendar pravičnejša, ker bo prosta zavisti in obrekljivosti. (44) Naposled moraš misliti še na to, da slave ne iščeš le zase; če bi tudi bilo tako, je vendar ne bi zametaval, zlasti ker si hotel, da bi bil spomin nate povzdignjen z najodličnejšimi pomniki. Toda svojo slavo moraš družiti z mojo, to morava zapustiti potomcem. Pri tem moraš paziti, da bi se, ko bi bil manj skrben, ne zdelo ne samo, da se ne trudiš zase, ampak tudi, da si še svojim sorodnikom zavisten.

(45) Vsega tega ne govorim, da bi bilo videti, kakor da so te moje besede zbudile iz spanja, temveč da bi se zdelo, da so te spodbudile v polni vnemi in teku. Zmeraj boš namreč počel, kar si že (doslej) počel, da bi vsi hvalili tvojo pravičnost, zmernost, strogost in nepodkupljivost. Vendar mi je zaradi edinstvene ljubezni do tebe posebej všeč tvoja nekako neizčrpna želja po slavi. Seveda sodim, da zdaj, ko ti mora biti Azija že tako domača kot komur koli drugemu njegova hiša in ko se je tvoji kar največji preudarnosti pridružilo toliko izkušenj, ni ničesar, kar prispeva k slavi, česar bi ti ne imel pred očmi in na kar ne bi brez kakršnega koli opozorila vsak dan mislil. Vendar - ker se mi zdi, da slišim tebe, kadar berem tvoja pisma, in da govorim s teboj, kadar ti pišem, se nadvse razveselim tvojih kar najdaljših pisem in sem tudi sam pri pisanju pogosto predolg.

(46) Na koncu te prosim in spodbujam, da bi, kakor je v navadi pri dobrih pesnikih in učinkovitih igralcih, tudi ti bil v zadnjem dejanju in ob zaključku svojega službovanja in opravila kar najskrbnejši, da bi se zdelo, da je bilo tretje leto tvojega upravništva (kot tretje dejanje) najpopolnejše in najodličnejše. To boš prav lahko dosegel, če boš mislil na to, da sem jaz, ki si mi samemu želel zmeraj bolj ugajati kakor vsem drugim, zmeraj s teboj, in da sem zraven pri vsem, kar boš govoril in delal.

C̆isto nazadnje te samo še prosim, da karseda prizadevno varuj svoje zdravje, če želiš, da bi bili zdravi jaz in vsi tvoji. 